\title{
ONE CITY TWO NOVELS
}

\section{Meral DEMIRRŸ̈REK}

Citation/(): Demiryürek, Meral, (2014). “One City Two Novels”, Hitit University Journal of Social Sciences Institute, Year 7, Issue 2, pp. 187-195

Abstract: Thessaloniki is a cultural and commercial city and it constitutes the settings for several contemporary novels, in that the cities location and historical background is important for Greeks, Bulgarians and Turks. In this study we will examine two novels, one of which was published in Turkey, Like a Sword Wound (Kllıç Yarası Gibi) by Ahmet Altan, and the other having been published in Greece, Skoteinos Vardaris by Elena Houzouri. Although the characters and the narrators of these two novels are different, they reflect the same time period and the same geography. These two novels tell us about the Balkan Wars and national bandits from the Turkish and from the Greek point of view, and Thessaloniki is one of the joint settings of the two novels previously mentioned. Therefore, the aim of this study is; to examine the different points of view, to compare these novels and show how historical events affect the literary works.

Keywords: Thessaloniki, Dark Vardar, Like a Sword Wound, Ahmet Altan, Elena Houzouri, Historical Novel.

Makale Geliş Tarihi: 19.06.2014/ Makale Kabul Tarihi: 29. 12. 2014

* Doç. Dr, Hitit Üniversitesi Fen Edebiyat Fakültesi Türk Dili ve Edebiyatı Bölümü, e-posta: meraldemiryurek@yahoo.com 


\section{Bir Şehir İki Roman}

Atıf/O: Demiryürek, Meral, (2014). "Bir Şehir İki Roman”, Hitit Üniversitesi Sosyal Bilimler Enstitüsü Dergisi, Yıl 7, Sayı 2, ss. 187-195.

Özet: Selanik, Osmanlı döneminde İzmir ve İstanbul gibi çok önemli kültür ve ticaret merkezleri arasindadir. Avrupa'ya yakin bir liman kenti olan Selanik'te farklı dinlerden, dillerden ve kültürlerden insanlar bir arada yaşarlar. Bütün bu özelliklerinden dolayı şehir, birçok edebî metne mekân teşkil eder. Selanik'in sadece Türkler için değil, Yunan ve Bulgarlar için de tarihî önemi vardır ve her üç milletin edebiyatlarinda da Selanik'i konu alan eserler bulunmaktadır.

Bu çalışmada Türk edebiyatından Ahmet Altan'ın Kllıç Yarası Gibi ve Yunan Edebiyatından Elena Houzouri'nin Karanlık Vardar romanları ele alınmıştır. Her iki roman da Selanik'te Balkan Savaşlarını ve Bulgar eşkıyalarını anlatmalar ortak paydasında buluşurlar. Yalnız konuyu Türk ve Yunan bakış açılarından anlatmalarıyla farklılaşırlar.

Bu çalışmanin amacl; edebî metinlerde aynı tarihî olaylara ve mekânlara yaklaşımda bakış açılarının nasıl farklılaşabildiğini incelemek ve kimi gerçek olayların edebî metinlere yansıma biçimlerini dikkatlere sunmaktır.

Anahtar Kelimeler: Selanik, Karanlık Vardar, Kılıç Yarası Gibi, Ahmet Altan, Elena Huzuri, Tarihî Roman.

\section{INTRODUCTION}

Some cities have different character on ethnics, cultural and commercial relations in the world. Especially, ports have big advantages for the connection of people. İstanbul, İzmir and Salonika were very popular big cities in the Ottoman Empire. Salonika, Salonica, Thessaloniki or Thessalonica was a city more complicated than others, because the population was mixed with Turks, Greeks, Bulgarians, Jewish and others. Salonika was founded by Cassander of Macedon in $316 \mathrm{BC}$; its name was derived from Thessalonica, the daughter of Philip the Second, wife of Cassander, and a half-sister of Alexander the Great. Salonika was one of the biggest cities of the Byzantine Empire. Ottoman armies raided the hinterland of Salonika in the middle of $14^{\text {th }}$ century and they captured the city. In this manner, Ottoman era in Salonika started in the $14^{\text {th }}$ century and lasted into the early years of the $20^{\text {th }}$ century. The city was one of the most important commercial centers for the Ottoman Empire in this period. 


\section{THESSALONIKI IN LIKE A SWORD WOUND}

Salonika is a big source for Turkish literature, on account of the early years of the $20^{\text {th }}$ century had many very important historical events and is the settings of many Turkish novels and short stories contained Salonika's this period, such as The Pain of Balkans (Balkan Acıst) by Y1lmaz Gürbüz, The Autumn of Salonika (Selanik'te Sonbahar) by Tuna Kiremitçi and Salonika with The Violet Caftan (Mor Kaftanlı Selanik) by Y1lmaz Karakoyunlu. Another of these novels is Like a Sword Wound (1998) by Ahmet Altan. This novel focuses on the last year's reign of Abdulhamid the Second and the activities of the Committee of Union and Progress (İttihat ve Terakki Fırkas1). Salonika was an Ottoman city in the early years of the $20^{\text {th }}$ century. There are a few important characters in this novel and one of them is Hilmi Bey who was appointed chief inspector of Salonika. Hilmi Bey his wife Mehpare and two children, moved to Salonika and were very happy living in this city, because Hilmi fell in love with Mehpare, their feelings once again arose for one another. Mehpare cooked special Cretan cuisines; Hilmi bought yogurt and cream from the Bulgarian milkman opposite the Ottoman Bank every day. But for this lovely family these conditions soon pasted. The city was no longer peaceful, and there was gossip that the Bulgarian komitadjis, resistance fighters, were preparing a rebellion against to the Ottoman government.

There are four events about Bulgarian terror in this novel; one of them took placed on the $15^{\text {th }}$ night in April. The electricity wasn't working throughout the entire city, due to an explosion at the Salonika train station by work of Bulgarian komitadjis. That same night many more explosions shocked the inhabitans of Salonika. The city theatre and New Mansion Café (Yeni Konak Gazinosu) were among these locations (p. 271). The next morning Hilmi Bey went to post office to make a telegraph, another terror event occurred; a Bulgarian rebel arrived at the post office. When the Ottoman soldiers learned there was a Bulgarian rebel inside, they started to fire upon the post office. Because of this Hilmi Bey and the other people inside the post office had to lie on the floor. The rebel had a few bombs, in which he threw the bombs outside. Because of this action many soldiers died, the rebel spoke "long lives the free Bulgaria!" and then he shot himself (p. 273-274). After a week had pasted, the people thought the worst was behind them. One morning they awoke to the most horrible noise they had heard in their lives. The windows in their homes were broken. Hilmi, his family and their servants were terrified by the shaking and the noise. When Hilmi looked through his broken window, he saw that the Ottoman Bank had been bombed. A short time later Hilmi learned that the 
Bulgarian milkman was a rebel, and his shop near the Ottoman Bank was not a normal milk, yogurt and cream shop. It was part of the plan in the Ottoman Bank bombing. Hilmi used to buy cream every day, but he didn't see anything amiss. After the bombing Hilmi didn't say anything about the milkman, because he was ashamed and he was afraid. Although he shopped every day from the Bulgarian milkman's shop, he did not suspect anything.

Chantal, was a French nanny caring for Hilmi's two children. She also has an extraordinary sexual relationship with Hilmi and his wife. When the terror actions started in Salonika, Chantal was very upset and afraid; she wanted to go back to France. Hilmi bought her a ticket and Chantal embarked on a journey to Marseilles with the ship named Guadalquivir. When the ship left from the Salonika port, the ship exploded work of the Bulgarian rebels. The ship was bombed by Pavel Shatev. Although some people and the Bulgarian komitadji, Pavel Shatev, were rescued, many people including Chantal died in this terror act. After this attack Hilmi and his wife were no longer happy. They lost their love for each other. Hilmi joined the Committee of Union and Progress. Mehpare met Konstantin Cesar Togliatti. He was of mixed race. His mother was Greek and father was Italian. Bulgarian problems increased and the Bulgarian revolution started at the end of this novel.

\section{THESSALONIKI IN DARK VARDAR}

It could be said that, Salonika has been a very big source for both Turkish and Greek literature and many novels have been written. But these novels have not been translated into other language completely yet. Readers don't realize the same, similar or the different points in the other cultures. Dark Vardar is a good example of point of view differences. The original Greek title of the book is Skoteinos Vardaris. It was published in 2004 by Kedros and was also published in Turkish by publishing house "Özgür." It was translated into Turkish by Suat Baran in 2009. Its Turkish name is Karanlı Vardar. Bir Rumeli Romani. The book was also translated into the Bulgarian language: "Dim Vardar." It was published in Bulgarian by publishing house "Ciela" and translated by Zdravka Michailova.

The author of the novel, Elena Houzouri, is not very popular in Turkey, even with her book translated into Turkish. In this paper, we focus on the Turkish edition. Possibly, this is the first study on this novel in Turkey. Actually, we focus on Dark Vardar, because the aim of this study is to release differences and similarities using the point of views from Dark Vardar and Like a Sword Wound. Two novels set in the same place: Salonika. Meleniko is also another important place. 
Elena Houzouri writes about historical details from the last part of Ottoman era. The plot contains widely characters, as Stephanos, George and Eleni. Salonika was important for Stephanos, because he went there for an education. He didn't just study in Salonika, he learned city life and it changed his character, but one thing did not change: His love for Eleni. Dark Vardar tells both a love story and about a historical period at the beginning of the $20^{\text {th }}$ century in Greek and Bulgarian societies. Therefore the reader follows the narrator's point of view thus seeing the Balkan problems. When French journalist Mişel Zarri met Hilmi Pasha who was governor of Macedonia, he asked him why the Ottoman Empire did not save the Greek citizens. On the other hand, Hilmi Pasha warned the French journalist that Bulgarian komidjas could abduct him. Perhaps Mişel Zarri was lucky and didn't see any guerrilla, but an American missionary woman, Ms Stown looking for excitement and adventure saw them. She met Sarafov's guerrilla group. Elena Houzouri used real historical people, like Hilmi Pasha and Sarafov. Especially, the author included Albert Kahn and August Leon in the Dark Vardar's plot. It is true that Albert Kahn (1840-1940) is known for his vast photographical project and museum throughout the entire world. According to the writer, Elena Houzouri, was inspired by a photograph in which her grandfather was in.

Ahmet Altan wrote the about ship bombing, because it is part of the plot. On the other side of fence Elena Houzouri, actually the narrator told us about the French ship, "Guadalquivir", bombing from the point of view of French newspapers. Consequently, there was the news from real French newspapers in this novel, such as Matin, Le Figaro and Journal. The newspapers described the Ottoman Empire as a "patient man", but they did not approve of this terror attack and of the Bulgarian guerillas. Houzouri used these details to reflect the political atmosphere from that time period.

The second similar historical event in the previously mentioned novels is the Ottoman Bank bombing in Salonika in 1903. Ahmet Altan tells this detail as an important part of the plot, but Elena Houzouri only wrote a couple of sentences about the Ottoman Bank bombing and then the bank building was rebuilt. The details are not the same in Like a Sword Wound and Dark Vardar, for example the Turkish novel tells the events taking place in 1903, and the Greek novel focuses the events taking place in 1911-1913. In addition to this, the point of views of the novels is different. However one can see some of the same similarities between these novels. To illustrate, the plots are similar. In other words both of them are postmodern novel; they are not ordinary historical novel and reflect different cultural values. 
Like a Sword Wound and Dark Vardar both partly set in Salonika in the early years of $20^{\text {th }}$ century. Hilmi and his wife, Mehpare, lived happily in the beginning, but they witnessed the Bulgarian terror attacks throughout the city and thus everything changed in their lives. On the other hand, the character of Dark Vardar, Stephanos, having went to Salonika and his life changing immediately. He studied and learned city life, but this changing did not provide to be a happy life for Eleni.

Each author reflects their own national perspectives in the novels. It is interesting that two novelist saw that the reasons of the Balkan problems was the Bulgarian guerrillas and the Ottoman sultan or pashas.

\section{THE SIMILARITIES OF THE STUDIED NOVELS}

There are a few similar details in the novels. Especially, the historical events of the Ottoman history reflect on the plot of the novels. The first joint point is the ship bombing. English Wikipedia writes this bombing as follows: "On the 28 April 1903, a member of the group, Pavel Shatev, used dynamite to blow up the French ship "Guadalquivir" which was leaving the Thessaloniki harbour." Ahmet Altan gives the name of Pavel Shatev who was a real person in the Balkan history. "Pavel Shatev (1882- 1951) was a Bulgarian revolutionary in that time and he blow up the Guadalquivir which was leaving Thessaloniki harbour. He was captured and sentenced to death, but later his sentence was changed to life imprisonment in Fezzan. In 1908, after the Young Turks revolution, Shatev was amnestied and went to Bulgaria. Later he graduated in law at Sofia University. In the next few years he worked as a teacher and journalist." (en. wikipedia.org/wiki/Pavel_Shatev)

Ahmet Altan wrote that the French ship, Guadalquivir, related to Chantal, French nanny, who wanted to go back to her country. In this novel it is a very important part of the plot. Considering Chantal is beloved by Hilmi and Mehpare both. When she died, they lost their family's happiness and the sexual relationship with each other. Therefore at the end of the novel Hilmi and Mehpare changed. Hilmi focused on political organization and Mehpare found a Greek-Italian lover.

The narrator of Dark Vardar told of the French ship bombing from the point of view of French newspapers. The newspapers did not approve of this terror attack or the Bulgarian guerillas. This event created a negative effect for Bulgarians. Therefore they lost their supporting of the French public opinion. Houzouri did not use her personal point of view in this event. She merely showed the French point of views through the use of newspapers. In addition 
to this, the newspapers names are real, and in this manner she added to fiction the reality of the French press history. Thanks to this style, Dark Vardar became a documentary novel. In fact, Elena Houzouri set up the novel with her grandfather's real life experiances.

The second similar historical event is the Ottoman Bank bombing in Salonika in 1903. Ahmet Altan also told this detail as an important part of the plot. Hilmi met a Bulgarian guerrilla as a milkman; he bought milk products from him every day. After the Ottoman Bank bombing, Hilmi understood everything, but he was ashamed and didn't say anything to police or any other government official. Were as Elena Houzouri just wrote a few sentences about Ottoman Bank bombing and that the bank building was rebuilt. An old woman helped Stephan when he went to Salonika and he was shown around the important places of Salonika by her. In that time, she showed the Ottoman Bank and shortly explained the history of the new bank building.

Ahmet Altan changed the chronological developments of these historical events in his novel. To illustrate the ship bombing is first, Ottoman Bank building bombing is the second event in the history. But Ahmet Altan wrote that the Ottoman Bank is bombing firstly, the ship bombing was second. Elena Houzuri obeyed the chronology and she wrote the ship bombing is first, and the Ottoman Bank bombing was second.

A. Altan and E.Houzouri used real historical people. Ahmet Altan gave the name of Pavel Shatev who was a real person in the Balkan history. He blew up the Guadalquivir while leaving the Thessaloniki harbor. Elena Houzoui included Hilmi Pasha, Albert Kahn and August Leon in Dark Vardar's plot. Albert Kahn is known for his vast photographical project and museum throughout the entire world. English Wikipedia writes as follows: "Albert Kahn (3 March 1860 - 14 November 1940) was a French banker and philanthropist, known for initiating The Archives of the Planet, a vast photographical project. Spanning 22 years, it resulted in a collection of 72,000 colored photographs and 183,000 meters of film." Albert Kahn was a real person and very important character in the novel, because he appointed August Leon as a photographer in the Balkans. August Leon took many photos some of which were of Stephan and some villager in Meleniko. If Albert Kahn had not thought of this project and had not sent August Leon, Stephan couldn't take the photo and, Elena Houzouri probably could not have written the novel Dark Vardar.

The fundamental part of these two novels is their narrators. Generally, classic novels have a third person narrator or first person narrator. In a second person 
narrator, one can see this style studied two novels, is rare but it has been also used by some novelists and storytellers. Dark Vardar and Like a Sword Wound have multiple narrators. There are three different narrators in the first novel. Elena Houzouri says "I did not write a classic novel, my novel is a postmodern novel." For this reason she used a second person narrator in Dark Vardar. Ahmet Altan also used a third and second person narrators. Especially second person narrator was extreme in his novel. Although Like a Sword Wound has a second person narrator partly, it is important and extraordinary for Turkish literature, because this type is rarely used with Turkish writers. Therefore there aren't a lot of examples with a second person narrator in the Turkish fiction. However a second person narrator is very popular among many other countries, like Greece.

The last similarity is the role of Salonika in the characters of the novels. In Like a Sword Wound, Hilmi and his wife, Mehpare, lived happily in the beginning, but they witnessed the Bulgarian terror attacks throughout the city and everything changed in their lives. The character of Dark Vardar, Stephanos, went to Salonika and his life changed immediately. He studied and learned city life, but this changing did not provide to be a happy life for Eleni.

\section{RESULTS}

Salonika affected both the Turkish and Greek novelists with its prominent historical role. Therefore a lot of novels have been written about its destiny.

The same historical events have reflected different points of view in the novels, the writers of these novels have been affected by their national culture.

The novels studied in this paper are interesting post-modern novels.

Although the novels studied in this paper use real historical people, consequently the events are presented as fictional texts.

Salonika played an important role in the lives of the characters in these novels. Changes in the Salonika city negatively affected the lives of the characters.

\section{REFERENCES}

AGOSTON G. and Masters B. (2009). Encyclopedia of Ottoman Empire. New York: Facts On File.

ALTAN, A. (2004). Kılıç Yarası Gibi. Istanbul: Alkım Yayınları. [In Turkish]

DEMIRÖZÜ D. Yunan Romanından Türk Anlatısına Yapılan Çeviriler Ya da İki Ülke İlişkilerinin Edebiyat Üzerinden Okunması.

DOĞAN, A. (2012). ‘Türk Edebiyatında Selanik’ VII.Uluslararası Büyük Türk Dili Kurultayı Bildiri Kitabı. Bilkent Üniversitesi, Ankara. [In Turkish] 
HUZURI, E. (2004). Dark Vardar. Athens: Kedros Press. [In Greek]

HUZURI, E. (2009). Karanlık Vardar. İstanbul: Özgür Yayınları. [In Turkish]

KARAKOYUNLU Y. (2012). Mor Kaftanlı Selanik. İstanbul: Doğan Yayınları. [In Turkish]

MILlAS H. (2003) Geçmişten Bugüne Yunanlılar. İstanbul: İletişim Yayınları. [In

Turkish]

NECATIGIL B. (1978). 'Balkan Ülkeleri Edebiyatlarından Türkçeye Çeviriler’ Türk Dili,

Çeviri Sorunları Özel Sayısı. S. 322, s. 126- 154. [In Turkish]

http://en.wikipedia.org/wiki/Boatmen_of_Thessalon\%C3\%ADki (accessed:

18.06.2014)

http://www.littera.hacettepe.edu.tr/TURKCE/20_cilt/demirozu.pdf (accessed:

18.06.2014) 
